\title{
The effect of compost on growth and yield of Phaseolus vulgaris plants grown under saline soil
}

\author{
Mostafa M. $\operatorname{Rady}^{1} \cdot$ Wael M. Semida ${ }^{2} \cdot$ Khaulood A. Hemida $^{3} \cdot$ Magdi T. Abdelhamid $^{4}$
}

Received: 5 July 2016/Accepted: 14 October 2016/Published online: 25 October 2016

(c) The Author(s) 2016. This article is published with open access at Springerlink.com

\begin{abstract}
Purpose The effect of a novel organo-mineral fertilizer (OMF) compost, as a partial alternative to mineral fertilizers, on soil characteristics, growth, physio-biochemical attributes, $\mathrm{Cd}^{2+}$ and $\mathrm{NO}_{3}{ }^{-}$concentrations, and yields of Phaseolus vulgaris L. plants grown under salt stress was investigated.

Methods Six organic and mineral materials were well mixed with water and composted in a polyvinyl house in a concrete trench of size $4 \times 5 \times 2 \mathrm{~m}(W \times L \times D)$, respectively. The moisture content was maintained at $50-60 \%$ throughout the active composting period by frequent checking. The mixture was turned at 7-day intervals for about 2 months to maintain porosity. This OMF compost was applied for the tested saline soil at 10, 20 and 30 ton $\mathrm{ha}^{-1}$ while reducing the recommended NPK to $50 \%$. In addition, $100 \%$ NPK was applied as a control to achieve the purpose of this study. Growth characteristics, quantitative and qualitative yield, $\mathrm{Cd}^{2+}$ and $\mathrm{NO}_{3}{ }^{-}$concentrations, and physio-biochemical attributes in common bean plants were assessed.

Results Addition of OMF compost improved the soil chemical and physical properties. Application of OMF
\end{abstract}

Mostafa M. Rady

mmr02@fayoum.edu.eg; mrady2050@gmail.com

1 Botany Department, Faculty of Agriculture, Fayoum University, Fayoum 63514, Egypt

2 Horticulture Department, Faculty of Agriculture, Fayoum University, Fayoum 63514, Egypt

3 Botany Department, Faculty of Science, Fayoum University, Fayoum 63514, Egypt

4 Botany Department, National Research Center, 33 Al Behoos Street, Cairo 12622, Egypt compost at a rate of 20 ton $\mathrm{h}^{-1}$, as an alternative to $50 \%$ of the recommended dose of mineral-NPK fertilizers, significantly decreased the concentrations of $\mathrm{Cd}^{2+}$ and $\mathrm{NO}_{3}{ }^{-}$in plant leaves, pods and seeds, showing the same growth characteristics, and pod and seed yields compared to the control (100\% of mineral-NPK fertilizers). This treatment also improved all determined physio-biochemical attributes and tested soil characteristics compared to the control. Conclusion The benefit of this OMF compost, as a partial alternative to chemical fertilizers, demonstrated the validity and possibility of sustainable agronomic performance of common bean using locally available recycled organic materials for manufacturing the studied OMF.

Keywords Common bean - Compost - Productivity · Cadmium $\cdot$ Nitrate $\cdot$ Salinity

\begin{tabular}{ll}
\multicolumn{2}{l}{ Abbreviations } \\
AADRs & Agricultural dry residues \\
AGRs & Agricultural green residues \\
Cd $^{2+}$ & Cadmium \\
Ca & Calcium \\
CEC & Cation exchange capacity \\
DDW & Double distilled water \\
DM & Dry mass \\
DW & Dry weight \\
EC & Electrical conductivity \\
EL & Electrolyte leakage \\
FYM & Farmyard manure \\
FM & Fresh mass \\
FW & Fresh weight \\
HA & Humic acid \\
KWs & Kitchen wastes \\
MSI & Membrane stability index \\
NPK & Mineral fertilizers
\end{tabular}




$\begin{array}{ll}\mathrm{NO}_{3}{ }^{-} & \text {Nitrate } \\ \mathrm{N} & \text { Nitrogen } \\ \mathrm{OM} & \text { Organic matter } \\ \mathrm{OMF} & \text { Organo-mineral fertilizer } \\ \mathrm{P} & \text { Phosphorus } \\ \mathrm{K} & \text { Potassium } \\ \mathrm{KH} & \text { Potassium humate } \\ \mathrm{RWC} & \text { Relative water content } \\ \mathrm{Na} & \text { Sodium } \\ \mathrm{S} & \text { Sulfur } \\ \mathrm{TS} \text { sugars } & \text { Total soluble sugars } \\ \mathrm{TM} & \text { Turgid mass } \\ \text { WHC } & \text { Water-holding capacity }\end{array}$

\section{Introduction}

Sustainable agriculture is, nowadays, an urgent requirement to minimize the environmental pollution that increased as a result of inadequate agricultural practices, including the extensive use of mineral fertilizers. The challenge of sustainable agriculture is more serious in developing countries, including Egypt. Mineral fertilizers are important for plant nutrition; however, they are also a potential sources of environmental pollution, particularly mineral-nitrogen $(\mathrm{N})$ and mineral-phosphorus $(\mathrm{P})$ fertilizers. The extensive application of mineral$\mathrm{N}$ fertilizers increases $\mathrm{NO}_{3}{ }^{-}$ions in the soil and consequently in the edible parts of plant grown in this soil (Rady 2011a). The $\mathrm{Cd}^{2+}$ is one of the heavy metals which causes loss in agricultural productivity and hazardous human health effects. One of the major anthropogenic sources of $\mathrm{Cd}^{2+}$ ions are Cd-containing mineral$P$ fertilizers (McLaughlin et al. 2000). Thus, the extensive use of mineral-P fertilizers leads to contamination by $\mathrm{Cd}^{2+}$ that is easily absorbed by roots and is frequently transported to other plant parts (Semida et al. 2015). In addition, farmers are suffering from declining soil fertility and increasing soil salinization, and consequently management of poor soil fertility in arid and semi-arid regions needs many effective solutions. This is due to the extensive use of mineral fertilizers, low rainfall, high evaporation rate, poor irrigation water and poor water management in these regions (Rady et al. 2013).

Attention is, therefore, focused on using various forms of OMF composts as partial substitutions to mineral fertilizers. These practices have been recommended (Ojo et al. 2014; Smith et al. 2015) under normal or saline conditions in arid and semi-arid regions as sources of nutrients, because these soils inherently have low organic matter and low mineralization (Okusami et al. 1997), due to high alkalinity and low rains. Because organic manures are characterized by slow release of nutrients, the complementary applications of organic manures with fast nutrient release-characterizing mineral fertilizers have been advocated. The beneficial effects of this practice in terms of improved crop productivity, soil fertility and sustainability, and balanced plant nutrition have been reported (Rady 2011a; Moyin-Jesu 2015; Riaz et al. 2015; Semida et al. 2015; Dotaniya et al. 2016; Kalaivanan and Hattab 2016; Kumar and Chopra 2016). In addition, application of FYM and green manures have positive effects on the soil characteristics (Kumar et al. 2014; Suja and Sreekumar 2014).

ADRs such as rice straw residue and sunflower plant parts (i.e., leaves, stems, and heads) are produced in large amounts as a by-product of crop productions in arid and semi-arid regions. A major portion of these ADRs is disposed by burning, mulched in crop fields, or discarded. In addition, AGRs (i.e., cauliflower and faba bean plants) and KWs are used in animal feed, are mulched in crop fields or are discarded. However, an attractive usage of all these residues/wastes is composting after they are mixed with some organic and mineral components, such as FYM, agricultural $\mathrm{S}$, and $\mathrm{KH}$ to produce OMF composts. Golueke (1972) had defined the composting process as a biological degradation of organic constituents in wastes under controlled conditions. The composting process has many advantages including sanitation, mass and bulk reduction, and also decrease of carbon to nitrogen $(\mathrm{C} / \mathrm{N})$ ratio. The ADRs are rich in $\mathrm{C}$ and are poor in $\mathrm{N}$, resulting in high $\mathrm{C} / \mathrm{N}$ ratio that can be decreased by adding the AGRs, KWs, FYM, and KH.

Common bean (Phaseolus vulgaris L.) is one of the most popular leguminous vegetable crops grown in the Middle Eastern countries for human diet due to its rich source of proteins, carbohydrates, and nutrients. Thus, cultivation of common bean and other different crop plants under soil application with OMF compost, as a partial alternative to mineral-NPK fertilizers, has the potential to increase crop production and soil sustainability (Abdelhamid et al. 2004; Rady 2011a; Ojo et al. 2014; Smith et al. 2015). This practice promoted higher plant growth and productivity and healthier human nutrition. It will also reduce mineral fertilizer use, reducing crop production cost and indirectly increasing income.

The objective of this study was to assess the effects of OMF compost applications at various levels as a partial alternative to mineral-NPK fertilizers on the growth, nutritional status, dehydration tolerance, osmoprotectants, green and dry yields, and quality of common bean (Phaseolus vulgaris L. cv. "Bronco") plants grown on a moderate saline soil. The physico-chemical characteristics of the tested soil were also assessed. 


\section{Materials and methods}

\section{Soil characteristics and composting the OMF}

The main characteristics of the experimental soil (a special Farm at Sherif Basha village, Beni Sueif Governorate; $29^{\circ} 06^{\prime} 20.4^{\prime \prime} \mathrm{N} ; 31^{\circ} 07^{\prime} 21.6^{\prime \prime} \mathrm{E}$ ) used in this research were determined and are shown in Table 1.

Six organic and mineral materials were prepared for manufacturing the OMF compost. They were ADRs (i.e.,

Table 1 Physico-chemical properties of the soil before treatments (BT) and at plant sampling (AT), and the compost

\begin{tabular}{|c|c|c|c|c|}
\hline \multicolumn{5}{|l|}{ The experimental soil } \\
\hline \multirow[t]{2}{*}{ Parameter } & \multicolumn{2}{|c|}{2012 season } & \multicolumn{2}{|c|}{2013 season } \\
\hline & BT & AT & BT & AT \\
\hline Clay & 49.4 & 50.3 & 49.8 & 50.5 \\
\hline Silt & 30.2 & 30.4 & 29.2 & 31.1 \\
\hline Sand & 20.4 & 19.3 & 21.0 & 18.4 \\
\hline Soil texture & Clay & & & \\
\hline $\mathrm{pH}$ & 7.79 & 7.14 & 7.83 & 7.05 \\
\hline $\mathrm{EC}\left(\mathrm{dS} \mathrm{m} \mathrm{m}^{-1}\right)$ & 6.73 & 5.83 & 6.78 & 5.77 \\
\hline $\mathrm{OM} \%$ & 0.93 & 1.39 & 0.89 & 1.40 \\
\hline $\mathrm{CEC}\left(\mathrm{cmol}_{\mathrm{c}} \mathrm{kg}^{-1}\right)$ & 34.9 & 42.7 & 34.5 & 43.1 \\
\hline Field capacity (\%) & 28.4 & 35.2 & 27.9 & 34.9 \\
\hline Available water (\%) & 12.8 & 16.9 & 12.4 & 16.6 \\
\hline Available $\mathrm{N}\left(\mathrm{mg} \mathrm{kg}^{-1}\right.$ soil) & 152.6 & 154.5 & 148.4 & 149.3 \\
\hline Available $\mathrm{P}\left(\mathrm{mg} \mathrm{kg}^{-1}\right.$ soil) & 12.2 & 13.2 & 11.4 & 12.9 \\
\hline Available $\mathrm{K}$ ( $\mathrm{mg} \mathrm{kg}^{-1}$ soil) & 144.2 & 163.7 & 138.9 & 171.8 \\
\hline Available $\mathrm{Fe}\left(\mathrm{mg} \mathrm{kg}^{-1}\right.$ soil $)$ & 21.2 & 24.6 & 19.3 & 23.7 \\
\hline Available Mn (mg kg ${ }^{-1}$ soil) & 11.0 & 13.4 & 11.5 & 15.2 \\
\hline Available $\mathrm{Zn}\left(\mathrm{mg} \mathrm{kg}^{-1}\right.$ soil $)$ & 4.1 & 4.8 & 3.9 & 5.0 \\
\hline Available $\mathrm{Cd}\left(\mathrm{mg} \mathrm{kg}^{-1}\right.$ soil) & 0.56 & 0.23 & 0.49 & 0.24 \\
\hline \multicolumn{5}{|l|}{ The OMF compost } \\
\hline Characteristic & \multicolumn{2}{|c|}{2012} & \multicolumn{2}{|c|}{2013} \\
\hline $\mathrm{pH}$ & \multicolumn{2}{|l|}{7.16} & \multicolumn{2}{|c|}{7.21} \\
\hline $\mathrm{EC}\left(\mathrm{dS} \mathrm{m} \mathrm{m}^{-1}\right)$ & \multicolumn{2}{|c|}{3.22} & \multicolumn{2}{|c|}{3.08} \\
\hline Total N (\% DW) & \multicolumn{2}{|l|}{2.18} & \multicolumn{2}{|c|}{2.28} \\
\hline Total C (\%) & \multicolumn{2}{|c|}{40.6} & \multicolumn{2}{|c|}{41.0} \\
\hline $\mathrm{C} / \mathrm{N}$ ratio & \multicolumn{2}{|l|}{18.6} & \multicolumn{2}{|c|}{18.0} \\
\hline $\mathrm{P}\left(\mathrm{g} \mathrm{kg}^{-1}\right.$ dry OMF $)$ & \multicolumn{2}{|c|}{3.05} & \multicolumn{2}{|c|}{2.98} \\
\hline $\mathrm{Na}\left(\mathrm{g} \mathrm{kg}^{-1}\right.$ dry OMF $)$ & \multicolumn{2}{|l|}{0.31} & \multicolumn{2}{|c|}{0.29} \\
\hline $\mathrm{Mg}\left(\mathrm{g} \mathrm{kg}^{-1}\right.$ dry OMF $)$ & \multicolumn{2}{|c|}{0.37} & \multicolumn{2}{|c|}{0.40} \\
\hline $\mathrm{Ca}\left(\mathrm{g} \mathrm{kg}^{-1}\right.$ dry $\left.\mathrm{OMF}\right)$ & \multicolumn{2}{|l|}{0.37} & \multicolumn{2}{|c|}{0.39} \\
\hline $\mathrm{K}\left(\mathrm{g} \mathrm{kg}^{-1}\right.$ dry OMF $)$ & \multicolumn{2}{|c|}{4.13} & \multicolumn{2}{|c|}{4.24} \\
\hline Total fibers (\% DW) & \multicolumn{2}{|l|}{32.4} & \multicolumn{2}{|c|}{33.1} \\
\hline WHC (g water/g dry OMF) & 6.18 & & & \\
\hline Moisture content (\%) & 39.3 & & & \\
\hline
\end{tabular}

Soil analysis was conducted for the treatment of $50 \%$ of the fully recommended NPK dose +20 ton OMF compost ha ${ }^{-1}$ rice straw, and sunflower leaves stems and heads), AGRs (i.e., cauliflower and faba bean plants), $\mathrm{KH}$, agricultural $\mathrm{S}$, and completely decomposed FYM and KWs. The ADRs, FYM, AGRs, KWs, S, and KH were used at a ratio of 50, $20,15,10,3$, and $2 \%$ by weight, respectively. The ADRs and AGRs were obtained from the farm in which the experiments were conducted. They were cut into small pieces, about $1-2 \mathrm{~cm}$ in length. In addition, FYM was obtained from the animal farm at the same place. With the addition of water, all six components were well mixed at the above-mentioned ratios and were composted in a polyvinyl house in a concrete trench of size $4 \times 5 \times 2 \mathrm{~m}$ $(W \times L \times D)$, respectively. The moisture content was maintained at 50-60\% throughout the active composting period by frequent checking with a Hydrosense moisture meter (Campbell Scientific, Inc., USA). The mixture was turned at 7-day intervals to maintain the porosity. At the end of the composting process (about 2 months), samples were taken for analysis (Table 1).

\section{Treatments and plant material}

Two field trials were conducted in two different fields at the same location, one in the 2012 season and one in the 2013 season. Before sowing, the control plots $\left(10.5 \mathrm{~m}^{2}\right.$ for each) received the complete dose of mineral-NPK [420 $\mathrm{kg} \mathrm{ha}^{-1}$ ammonium sulfate $(21 \% \mathrm{~N}), 460 \mathrm{~kg} \mathrm{ha}^{-1}$ calcium superphosphate $\left(15.5 \% \mathrm{P}_{2} \mathrm{O}_{5}\right)$ and $230 \mathrm{~kg} \mathrm{ha}^{-1}$ potassium sulfate $\left(48 \% \mathrm{~K}_{2} \mathrm{O}\right)$ ] fertilizers, as recommended by the Egyptian Ministry of Agriculture and Land Reclamation. The other treatments were as follows:

\begin{tabular}{lll}
\hline Treatment & Recommended NPK dose & OMF compost \\
\hline Control & $100 \%$ & - \\
1 & $50 \%$ & 10 ton ha \\
2 & $50 \%$ & 20 ton ha $^{-1}$ \\
3 & $50 \%$ & 30 ton ha \\
\hline
\end{tabular}

The OMF compost was spread on the soil surface and then mixed into the soil surface layer during soil preparation for sowing. All treatments were applied in a randomized complete block design with three replicates. Sowing was conducted on 25 February 2012 and on 23 February 2013. Common bean (Phaseolus vulgaris L. cv. "Bronco") seeds obtained from the Agricultural Research Center, Giza, Egypt, were used. Seeds were selected for uniformity by choosing those of equal size and of the same color. The selected seeds were washed with distilled water, sterilized in $1 \%(\mathrm{v} / \mathrm{v})$ sodium hypochlorite for approximately $2 \mathrm{~min}$, washed thoroughly again with distilled water, and left to dry at room temperature $\left(25^{\circ} \mathrm{C}\right)$ for approximately $1 \mathrm{~h}$. Uniform, air-dried seeds were sown in 
hills in rows spaced $60 \mathrm{~cm}$ apart. The hills were spaced $10-15 \mathrm{~cm}$ apart in $3.0 \mathrm{~m} \times 3.5 \mathrm{~m}$ plots. Thinning was done before the first irrigation to produce two plants per hill. All other standard cultural practices were followed, as recommended by the Egyptian Ministry of Agriculture and Land Reclamation for commercial common bean production (Egyptian Ministry of Agriculture 2011).

\section{Plant growth and yield estimations}

Seven-week-old bean plants $(n=9)$ were carefully removed from each experimental plot and dipped in a bucket of water. Plants were shaken gently to remove all adhering soil particles and the lengths of their shoots and roots were measured using a meter scale. The number of leaves plant ${ }^{-1}$ was counted and their area was measured manually using a graph sheet, where the squares covered by the leaf were counted. The plants were then placed in an oven at $70{ }^{\circ} \mathrm{C}$ until constant weight to record DW. At the marketable green pod, pods were collected 2-day intervals to record the average pod weight per plant and per hectare. At the end of each experiment, all the dry pods on each plant in each experimental plot were collected and the seeds were extracted from pods to record seed weight per plant and per hectare.

\section{Determination of photosynthetic pigments, nutrients, and $\mathrm{Cd}^{2+}$ and $\mathrm{NO}_{3}{ }^{-}$concentrations}

Concentrations of chlorophylls and carotenoids $\left(\mathrm{mg} \mathrm{g}^{-1}\right.$ FW) were estimated according to the method described by Arnon (1949). Leaf discs (0.2 g) of the third leaf from the top of 7-week-old plants were homogenized with $50 \mathrm{ml}$ $80 \%$ acetone. The slurry was strained through a cheesecloth and the extract was centrifuged at $15,000 \times g$ for $10 \mathrm{~min}$. The optical density of the acetone extract was measured at 663, 645, and $470 \mathrm{~nm}$ using a UV-160A UV Visible Recording Spectrometer, Shimadzu, Japan.

The content of $\mathrm{N}(\%)$ in dried bean leaf (third leaf from the top) was determined by using the micro-Kjeldahl method (AOAC 1995). The molybdenum-reduced molybdophosphoric blue color method in sulfuric acid (with reduction to exclude arsenate) was used to determine the $\mathrm{P}$ content (\%) as described by Jackson (1967). In this method, sulfomolybdic acid (molybdenum blue), diluted sulfomolybdic acid, and $8 \%(\mathrm{w} / \mathrm{v})$ sodium bisulfite- $\mathrm{H}_{2} \mathrm{SO}_{4}$ solution were used as reagents. The contents of $\mathrm{Ca}^{2+}$ (in leaves) and $\mathrm{Cd}^{2+}$ (in leaves, pods, and seeds) were determined using a Perkin-Elmer Model 3300 Atomic Absorption Spectrophotometer (Chapman and Pratt 1961). The contents of $\mathrm{K}^{+}(\%)$ and $\mathrm{Na}^{+}(\%)$ were determined in $\mathrm{H}_{2-}$ $\mathrm{SO}_{4}+\mathrm{H}_{2} \mathrm{O}_{2}$-digested solution of $0.2 \mathrm{~g}$ of a dried bean leaf (third leaf from the top) (Wolf 1982). The total leaf contents of $\mathrm{Na}^{+}$and $\mathrm{K}^{+}$were measured directly using flame spectrophotometry (Lachica et al. 1973).

Leaf, pod, and seed samples were collected and kept in a refrigerator $\left(4^{\circ} \mathrm{C}\right)$. The samples were cut to small pieces and squeezed in a stainless steel press to obtain sap. The sap was then used to measure the $\mathrm{NO}_{3}{ }^{-}$concentration using a Cardy $\mathrm{NO}_{3}{ }^{-}$-meter (Spectrum Technologies, Inc. Springfield, IL, USA) following the method described by Zhang (1998).

\section{Determination of free proline and TS sugar concentrations}

As suggested by Bates et al. (1973), free proline was extracted by grinding $0.5 \mathrm{~g}$ leaf sample in $10 \mathrm{ml} 3 \%(\mathrm{v} / \mathrm{v})$ sulfosalicylic acid and was then centrifuged at $10,000 \times g$ for $10 \mathrm{~min}$. The acid ninhydrin $(2 \mathrm{ml})$ was added to the supernatant $(2 \mathrm{ml})$ and incubated in a water bath at $90{ }^{\circ} \mathrm{C}$ for $30 \mathrm{~min}$. The reaction was cool terminated and the mixture was extracted with toluene, vortex mixed for $15 \mathrm{~s}$, and the toluene phase was read at $520 \mathrm{~nm}$.

According to Irigoyen et al. (1992), TS sugars were extracted from dried leaves (0.2 g) using ethanol (96\%). After centrifugation, the supernatant was stored at $4{ }^{\circ} \mathrm{C}$. Determination was conducted by reacting $0.1 \mathrm{ml}$ of the ethanolic extract with $3 \mathrm{ml}$ of freshly prepared anthrone reagent $[150 \mathrm{mg}$ anthrone $+100 \mathrm{ml}$ of $72 \%(\mathrm{v} / \mathrm{v})$ sulfuric acid] in a boiling water bath for $10 \mathrm{~min}$. After cooling, the mixture was read at $625 \mathrm{~nm}$.

\section{Measurement of RWC, MSI, and EL}

Excluding the midrib, fresh $2 \mathrm{~cm}$-diameter fully expanded leaf discs were used to determine the RWC as described by Hayat et al. (2007). The FM of discs were taken and immediately floated on double-distilled water in Petri dishes for $24 \mathrm{~h}$, in the dark, to saturate them with water. Any adhering water was blotted dry and the TM was measured. The DM was recorded after dehydrating the discs at $70{ }^{\circ} \mathrm{C}$ until constant weight. The RWC was then calculated using the formula:

$\operatorname{RWC}(\%)=[(\mathrm{FM}-\mathrm{DM}) /(\mathrm{TM}-\mathrm{DM})] \times 100$.

The MSI was estimated using duplicate $0.2 \mathrm{~g}$ samples of leaf tissue as described by Premchandra et al. (1990) and modified by Rady (2011b). Samples were placed in test tubes containing $10 \mathrm{ml}$ of DDW. One sample was heated at $40{ }^{\circ} \mathrm{C}$ in a water bath for $30 \mathrm{~min}$ and the EC of the solution was recorded using a conductivity bridge $\left(\mathrm{C}_{1}\right)$. The second sample was boiled at $100{ }^{\circ} \mathrm{C}$ for $10 \mathrm{~min}$ and the EC was measured $\left(\mathrm{C}_{2}\right)$. The MSI was calculated using the formula: $\operatorname{MSI}(\%)=\left[1-\left(\mathrm{C}_{1} / \mathrm{C}_{2}\right)\right] \times 100$. 
The total leakage of inorganic ions from leaves was determined using the method of Sullivan and Ross (1979). Twenty leaf discs were placed in a boiling tube containing $10 \mathrm{ml}$ deionized water and the $\mathrm{EC}_{1}$ was recorded. The contents were then heated to $45-55^{\circ} \mathrm{C}$ for 30 min each in a water bath and the $\mathrm{EC}_{2}$ was recorded. The sample was boiled at $100{ }^{\circ} \mathrm{C}$ for $10 \mathrm{~min}$ and the $\mathrm{EC}_{3}$ was recorded. The EL was calculated using the formula:

$\mathrm{EL}(\%)=\left[\left(\mathrm{EC}_{2}-\mathrm{EC}_{1}\right) / \mathrm{EC}_{3}\right] \times 100$.

\section{Statistical analysis}

Simple analysis of variance (ANOVA) was used to analyze the data. Significant differences between means were compared using Fisher's least-significant difference (LSD) test at a probability level of $95 \%(P \leq 0.05)$.

\section{Results and discussion}

\section{Soil physical and chemical properties}

The effect of OMF compost application at 20 ton $^{\text {ha }}{ }^{-1}$ on soil physical and chemical properties is presented in Table 1. By the end of both the 2012 and 2013 seasons, the OMF compost decreased soil $\mathrm{EC}_{\mathrm{e}}$ and $\mathrm{pH}$ values. The reduction in $\mathrm{pH}$ values could be attributed to the accumulation of active organic acids and $\mathrm{S}$ (a component of OMF compost) in soil and the CEC of humate (a component of OMF compost). Soil $\mathrm{EC}_{\mathrm{e}}$ values tends to decrease probably due to the occurrence of the charged sites (i.e., COO-), accounts for the ability of humate to chelate, and retains cation in non-active forms (Semida et al. 2014; Ouni et al. 2014). In addition, the reduced EC of the OMF compost (3.08-3.22 $\mathrm{dS} \mathrm{m} \mathrm{m}^{-1}$; Table 1) contributed to decrease the soil $\mathrm{EC}_{\mathrm{e}}$. Elemental $\mathrm{S}$ is biologically oxidized to $\mathrm{H}_{2} \mathrm{SO}_{4}$ in soil under aerobic conditions. This is beneficial in alkaline soils to reduce $\mathrm{pH}$, supplying of $\mathrm{SO}_{4}$ to plants, make $\mathrm{P}$ more available, and reclaim soils. Application of elemental $\mathrm{S}$ to the soil resulted in 0.11-0.37 unit decrease in soil pH (Erdal et al. 2000). Application of OMF compost increased soil OM content from $0.89-0.93 \%$ to $1.39-1.40 \%$, and available contents of the studied macronutrients (i.e., $\mathrm{N}, \mathrm{P}$, and $\mathrm{K}$ ) and micronutrients (i.e., $\mathrm{Fe}, \mathrm{Mn}$, and $\mathrm{Zn}$ ). Combined positive effect of HA and $\mathrm{S}$ were also reported by Osman and Rady (2012). They attributed their positive effects on the soil to the increase of OM content and bio-available nutrients, as a result of a reduction in soil $\mathrm{pH}$. The addition of OMF compost to saline soil encouraged the creation of medium and micropores (i.e., WHC and useful pores) between simple packing sand particles, and in turn increasing the capillary potential. The above-mentioned case is more attributed to an increase in soil moisture content at field capacity and then available water content (Habashy and Ewees 2011), due to the increased content of total fibers (32.3-33.1\%) and also the increased WHC of OMF compost (6.18-6.32 g water/g OMF compost; Table 1). The effects of OMF components on improving soil properties such as aggregation, aeration, permeability, and WHC were positive, which led to maintain the appropriate water content in the soil and hence increased the activity of the immune plant system.

\section{Growth characteristics}

As an alternative to $50 \%$ of the recommended dose of NPK, addition of OMF compost at a rate of 10 ton $\mathrm{ha}^{-1}$ showed significant decreases $(P \leq 0.05)$, while addition of a rate of 20 or 30 ton $\mathrm{h}^{-1}$ exhibited no significant differences $(P \leq 0.05)$ in plant growth characteristics (in terms of shoot and root lengths, number of leaves plant ${ }^{-1}$, leaf area plant ${ }^{-1}$, and plant DW) when compared with the control treatment $(100 \%$ of the recommended dose of NPK; Table 2). The same trends were seen in both the 2012 and 2013 seasons. The improved growth characteristics of common bean plants produced as a result of increased application rate of OMF compost could be attributed to the enhanced decomposition of the $\mathrm{OM}$ and mineralization of nutrients (Abdelhamid et al. 2004; Ojo et al. 2014). In addition, the suggestion that KH (a component of the OMF compost) has a direct action on plants as a hormonal nature (cytokinins and auxin-like activity), and an indirect action of metabolic soil microorganisms as soon as the dynamic of uptake of soil nutrients and soil physical properties, reflecting in an enhancement of plant growth and productivity (Osman and Rady 2012; Semida et al. 2014; Ouni et al. 2014). The benefits of $\mathrm{KH}$ as an additive to the OMF compost may be due to its effects on increased fertilizer use efficiency and soil aeration. In addition, the presence of nutrient elements, the increased contents of total fibers, and the appropriate WHC in the OMF compost (Table 1) increased the overall fertility, stability, and functionality of the tested soil, leading to maintain plant growth equal to the growth of plants fertilized with $100 \%$ of the recommended NPK dose. Adding the OMF compost to the saline soils may have compensated them for any physico-chemical defects. Various soil micro-organisms may benefit from some components of the OMF compost to increase their excretions of vitamins, growth substances, and antibiotics that can further promote plant growth (Osman and Rady 2012; Semida et al. 2014; Ojo et al. 2014). 
Table 2 Effect of OMF compost as a partial substitution of NPK on the growth traits of Phaseolus vulgaris plants grown under soil salinity

\begin{tabular}{|c|c|c|c|c|c|c|}
\hline \multicolumn{2}{|l|}{ Treatments } & \multicolumn{5}{|l|}{ Parameters } \\
\hline $\begin{array}{l}\text { Recommended NPK } \\
\text { dose }\end{array}$ & $\begin{array}{l}\text { OMF compost } \\
\left(\text { ton } \mathrm{h}^{-1} \text { ) }\right.\end{array}$ & $\begin{array}{l}\text { Shoot length } \\
(\mathrm{cm})\end{array}$ & $\begin{array}{l}\text { Root length } \\
(\mathrm{cm})\end{array}$ & $\begin{array}{l}\text { No. of leaves } \\
\text { plant }^{-1}\end{array}$ & $\begin{array}{l}\text { Leaf area plant } \\
\left(\mathrm{dm}^{2}\right)\end{array}$ & Plant DW (g) \\
\hline \multicolumn{7}{|l|}{2012 season } \\
\hline \multirow[t]{2}{*}{ Control (100\% NPK) } & & $25.3 \pm 1.4 \mathrm{a}$ & $21.3 \pm 1.7 \mathrm{a}$ & $7.85 \pm 0.43 a$ & $10.35 \pm 0.63 \mathrm{a}$ & $6.33 \pm 0.41 \mathrm{a}$ \\
\hline & 10 & $21.2 \pm 1.1 \mathrm{~b}$ & $18.2 \pm 1.2 \mathrm{~b}$ & $7.10 \pm 0.41 b$ & $9.23 \pm 0.55 b$ & $5.44 \pm 0.38 b$ \\
\hline \multirow[t]{2}{*}{$50 \%$} & 20 & $25.4 \pm 1.6 \mathrm{a}$ & $22.4 \pm 1.9 \mathrm{a}$ & $8.12 \pm 0.47 \mathrm{a}$ & $10.56 \pm 0.66 \mathrm{a}$ & $6.48 \pm 0.42 \mathrm{a}$ \\
\hline & 30 & $25.9 \pm 1.6 \mathrm{a}$ & $21.7 \pm 1.8 \mathrm{a}$ & $7.98 \pm 0.45 \mathrm{a}$ & $10.37 \pm 0.64 \mathrm{a}$ & $6.40 \pm 0.41 \mathrm{a}$ \\
\hline \multicolumn{7}{|l|}{2013 season } \\
\hline \multirow[t]{2}{*}{ Control (100\% NPK) } & & $27.8 \pm 1.7 \mathrm{a}$ & $21.0 \pm 1.4 \mathrm{a}$ & $7.46 \pm 0.51 \mathrm{ab}$ & $10.40 \pm 0.73 \mathrm{a}$ & $6.52 \pm 0.54 a$ \\
\hline & 10 & $21.9 \pm 1.2 \mathrm{~b}$ & $19.2 \pm 1.2 \mathrm{~b}$ & $6.98 \pm 0.42 b$ & $9.07 \pm 0.64 b$ & $5.38 \pm 0.44 b$ \\
\hline \multirow[t]{2}{*}{$50 \%$} & 20 & $28.1 \pm 1.7 \mathrm{a}$ & $21.8 \pm 1.6 \mathrm{a}$ & $8.04 \pm 0.56 \mathrm{a}$ & $10.45 \pm 0.72 \mathrm{a}$ & $6.60 \pm 0.55 \mathrm{a}$ \\
\hline & 30 & $27.7 \pm 1.5 \mathrm{a}$ & $21.6 \pm 1.5 \mathrm{a}$ & $8.11 \pm 0.58 \mathrm{a}$ & $10.54 \pm 0.75 \mathrm{a}$ & $6.72 \pm 0.58 \mathrm{a}$ \\
\hline
\end{tabular}

Values are mean \pm SE $(n=10)$. Mean values in each column followed by different lowercase letters are significantly different by Fisher's leastsignificant difference test (LSD) at $P \leq 0.05$

\section{Leaf photosynthetic pigments, free proline, and TS sugars}

Application of OMF compost at a rate of 10 ton $^{-1}$, as an alternative to $50 \%$ of the recommended dose of NPK, revealed significant reductions $(P \leq 0.05)$ in the concentrations of total chlorophylls, total carotenoids, free proline, and TS sugars. However, application at a rate of 20 or 30 ton $\mathrm{h}^{-1}$ exhibited no significant differences $(P \leq 0.05)$ in the concentrations of total chlorophylls and total carotenoids, but showed further reductions $(P \leq 0.05)$ in the concentrations of free proline and TS sugars when compared with the control treatment $(100 \%$ of the recommended dose of NPK; Table 3). The same trend was observed over both growing seasons. The application of OMF compost increased the uptake rate of elemental $\mathrm{K}$ and other nutrient elements (Table 4) and, therefore, a corresponding increase in chlorophyll content, which can serve as an indicator of the stress induced by alterations in the balance of endogenous hormones (Marschner 1995). The reductions in free proline and TS sugar concentrations in common bean plants by the application of OMF compost may be attributed to the crucial role of OMF compost in mitigating the negative salt effects in other manners. These reductions in free proline and TS sugars may be attributed to the presence of $\mathrm{KH}$ and $\mathrm{S}$ : two components of the OMF and their roles in alleviating the salt stress effects. Kulikova et al. (2005) pointed out that humic substances might show anti-stress effects under abiotic stress conditions, decreasing free proline content. Further, Osman and Rady (2012) observed that $S$ and HA were beneficial for newly reclaimed saline soils to alleviate the adverse effects of salinity stress and to improve sustainable crop productivity. Compost could have favored leaf growth and a new sink developed which would reduce soluble carbohydrates (Isopp et al. 2000).

\section{RWC, EL, and MSI}

As compared to the control treatment (100\% of the recommended dose of NPK), bean plants treated by either 20 or 30 ton OMF compost $\mathrm{h}^{-1}$, as an alternative to $50 \%$ of the recommended NPK dose, revealed a significant increase in dehydration tolerance in terms of increased RWC and MSI and reduced EL (Table 3). However, application of 10 ton OMF compost $\mathrm{h}^{-1}$ significantly increased $(P \leq 0.05)$ MSI, significantly decreased $(P \leq 0.05) \mathrm{EL}$, and had no effect on RWC. The same trends were observed in both the 2012 and 2013 seasons. The RWC, a measure of plant water status, reflecting the metabolic activity in plant tissues, is used as a most meaningful index to identify the legumes with contrasting differences in dehydration tolerance (Sinclair and Ludlow 1986). A strong relationship was observed between RWC and plant biomass (FW and DW) under the effect of OMF compost combined with reducing the NPK to $50 \%$ of the recommended dose, indicating that water status in bean leaves is basically dependent on the respective shoot biomass. This also suggests that common bean plants having greater biomass can maintain higher water content in their leaves and thus can be more tolerant to salinity stress. The increase in RWC as a result of OMF compost application reflected more stable cellular membranes, and therefore the leakage of ions from cells reduced significantly under salinity stress.

\section{Plant nutritional status}

The content of mineral nutrients (i.e., N, P, K, and $\mathrm{Ca}$ ) and $\mathrm{Na}$, as well as the ratios of $\mathrm{K}^{+}: \mathrm{Na}^{+}$and $\mathrm{Ca}^{2+}: \mathrm{Na}^{+}$of 
Table 3 Effect of OMF compost as a partial substitution of NPK on leaf concentration of photosynthetic pigment, osmoprotectants, RWC (\%), EL (\%), and MSI (\%) of Phaseolus vulgaris plants grown under soil salinity

\begin{tabular}{|c|c|c|c|c|c|c|c|c|}
\hline \multicolumn{2}{|l|}{ Treatments } & \multicolumn{7}{|l|}{ Parameters } \\
\hline $\begin{array}{l}\text { Recommended } \\
\text { NPK dose }\end{array}$ & $\begin{array}{l}\text { OMF } \\
\text { compost } \\
\left(\text { ton } h^{-1}\right)\end{array}$ & $\begin{array}{l}\text { Total } \\
\text { chlorophylls } \\
\left(\mathrm{mg} \mathrm{g}^{-1} \mathrm{FW}\right)\end{array}$ & $\begin{array}{l}\text { Total } \\
\text { carotenoids } \\
\left(\mathrm{mg} \mathrm{g}^{-1} \mathrm{FW}\right)\end{array}$ & $\begin{array}{l}\text { Free proline } \\
\left(\mu \mathrm{g} \mathrm{g}^{-1} \mathrm{DW}\right)\end{array}$ & $\begin{array}{l}\text { TS sugars } \\
\left(\mathrm{mg} \mathrm{g}^{-1} \mathrm{DW}\right)\end{array}$ & RWC (\%) & EL (\%) & MSI (\%) \\
\hline \multicolumn{9}{|l|}{2012 season } \\
\hline \multirow[t]{2}{*}{ Control (100\% } & NPK) & $1.30 \pm 0.03 \mathrm{a}$ & $0.26 \pm 0.01 \mathrm{a}$ & $221.5 \pm 4.2 \mathrm{a}$ & $3.63 \pm 0.07 \mathrm{a}$ & $74.6 \pm 1.6 b$ & $11.24 \pm 0.31 \mathrm{a}$ & $61.9 \pm 1.4 \mathrm{c}$ \\
\hline & 10 & $1.16 \pm 0.02 b$ & $0.22 \pm 0.01 b$ & $209.6 \pm 3.7 b$ & $3.38 \pm 0.05 b$ & $73.9 \pm 1.4 b$ & $9.62 \pm 0.26 b$ & $66.3 \pm 1.7 b$ \\
\hline \multirow[t]{2}{*}{$50 \%$} & 20 & $1.31 \pm 0.03 \mathrm{a}$ & $0.25 \pm 0.01 \mathrm{a}$ & $189.4 \pm 2.1 \mathrm{c}$ & $3.07 \pm 0.07 \mathrm{c}$ & $81.2 \pm 1.8 \mathrm{a}$ & $8.44 \pm 0.21 c$ & $75.4 \pm 2.1 \mathrm{a}$ \\
\hline & 30 & $1.33 \pm 0.03 \mathrm{a}$ & $0.26 \pm 0.01 \mathrm{a}$ & $182.6 \pm 2.0 \mathrm{c}$ & $3.01 \pm 0.08 \mathrm{c}$ & $82.0 \pm 1.9 \mathrm{a}$ & $8.17 \pm 0.19 c$ & $77.2 \pm 2.3 \mathrm{a}$ \\
\hline \multicolumn{9}{|l|}{2013 season } \\
\hline \multirow[t]{2}{*}{ Control (100\% } & NPK) & $1.36 \pm 0.02 \mathrm{a}$ & $0.28 \pm 0.01 \mathrm{a}$ & $232.8 \pm 5.2 \mathrm{a}$ & $3.72 \pm 0.06 \mathrm{a}$ & $74.1 \pm 1.8 b$ & $12.32 \pm 0.43 a$ & $63.4 \pm 1.3 \mathrm{c}$ \\
\hline & 10 & $1.23 \pm 0.02 b$ & $0.25 \pm 0.01 b$ & $210.5 \pm 4.8 b$ & $3.41 \pm 0.05 b$ & $75.8 \pm 1.9 \mathrm{~b}$ & $9.56 \pm 0.31 b$ & $68.6 \pm 1.5 b$ \\
\hline \multirow[t]{2}{*}{$50 \%$} & 20 & $1.40 \pm 0.03 \mathrm{a}$ & $0.29 \pm 0.01 \mathrm{a}$ & $186.7 \pm 3.2 \mathrm{c}$ & $3.12 \pm 0.07 \mathrm{c}$ & $83.2 \pm 2.3 a$ & $8.34 \pm 0.25 c$ & $74.8 \pm 1.8 \mathrm{a}$ \\
\hline & 30 & $1.41 \pm 0.03 \mathrm{a}$ & $0.28 \pm 0.01 \mathrm{a}$ & $174.4 \pm 2.8 \mathrm{c}$ & $3.10 \pm 0.09 \mathrm{c}$ & $83.9 \pm 2.5 a$ & $7.93 \pm 0.23 c$ & $76.3 \pm 2.0 \mathrm{a}$ \\
\hline
\end{tabular}

Values are mean \pm SE $(n=10)$. Mean values in each column followed by different lowercase letters are significantly different by Fisher's leastsignificant difference test (LSD) at $P \leq 0.05$

Table 4 Effect of OMF compost as a partial substitution of NPK on the contents of nutrients and Na, and their relations in Phaseolus vulgaris plants grown under soil salinity

\begin{tabular}{|c|c|c|c|c|c|c|c|c|}
\hline \multicolumn{2}{|l|}{ Treatments } & \multicolumn{7}{|l|}{ Parameters } \\
\hline $\begin{array}{l}\text { Recommended } \\
\text { NPK dose }\end{array}$ & $\begin{array}{l}\text { OMF } \\
\text { compost (ton } \\
\mathrm{h}^{-1} \text { ) }\end{array}$ & $\mathrm{N}(\%)$ & $\mathrm{P}(\%)$ & $\mathrm{K}(\%)$ & $\mathrm{Ca}(\%)$ & $\mathrm{Na}(\%)$ & $\mathrm{K} / \mathrm{Na}$ ratio & $\mathrm{Ca} / \mathrm{Na}$ ratio \\
\hline \multicolumn{9}{|l|}{2012 season } \\
\hline \multicolumn{2}{|c|}{ Control (100\% NPK) } & $2.75 \pm 0.05 \mathrm{a}$ & $0.25 \pm 0.008 \mathrm{a}$ & $3.31 \pm 0.05 \mathrm{a}$ & $1.43 \pm 0.03 \mathrm{a}$ & $1.18 \pm 0.03 \mathrm{a}$ & $2.81 \pm 0.06 \mathrm{c}$ & $1.21 \pm 0.03 \mathrm{c}$ \\
\hline \multirow{3}{*}{$50 \%$} & 10 & $2.49 \pm 0.05 b$ & $0.23 \pm 0.006 b$ & $3.12 \pm 0.04 b$ & $1.24 \pm 0.02 b$ & $1.05 \pm 0.03 b$ & $2.97 \pm 0.06 \mathrm{c}$ & $1.18 \pm 0.03 \mathrm{c}$ \\
\hline & 20 & $2.78 \pm 0.06 \mathrm{a}$ & $0.25 \pm 0.007 \mathrm{a}$ & $3.34 \pm 0.04 \mathrm{a}$ & $1.38 \pm 0.03 \mathrm{a}$ & $0.90 \pm 0.02 \mathrm{c}$ & $3.71 \pm 0.07 \mathrm{~b}$ & $1.53 \pm 0.04 b$ \\
\hline & 30 & $2.80 \pm 0.06 \mathrm{a}$ & $0.26 \pm 0.008 \mathrm{a}$ & $3.36 \pm 0.05 \mathrm{a}$ & $1.40 \pm 0.03 \mathrm{a}$ & $0.76 \pm 0.02 \mathrm{~d}$ & $4.42 \pm 0.09 \mathrm{a}$ & $1.84 \pm 0.05 \mathrm{a}$ \\
\hline \multicolumn{9}{|l|}{2013 season } \\
\hline \multicolumn{2}{|c|}{ Control (100\% NPK) } & $2.91 \pm 0.04 \mathrm{a}$ & $0.30 \pm 0.010 \mathrm{a}$ & $3.41 \pm 0.06 \mathrm{a}$ & $1.66 \pm 0.04 \mathrm{a}$ & $1.26 \pm 0.03 \mathrm{a}$ & $2.71 \pm 0.05 \mathrm{c}$ & $1.32 \pm 0.03 \mathrm{c}$ \\
\hline \multirow{3}{*}{$50 \%$} & 10 & $2.55 \pm 0.03 b$ & $0.27 \pm 0.008 \mathrm{~b}$ & $3.14 \pm 0.05 b$ & $1.38 \pm 0.03 b$ & $1.12 \pm 0.02 b$ & $2.80 \pm 0.06 \mathrm{c}$ & $1.23 \pm 0.02 \mathrm{c}$ \\
\hline & 20 & $2.95 \pm 0.04 \mathrm{a}$ & $0.31 \pm 0.011 \mathrm{a}$ & $3.40 \pm 0.06 a$ & $1.69 \pm 0.04 \mathrm{a}$ & $0.97 \pm 0.02 \mathrm{c}$ & $3.51 \pm 0.08 \mathrm{~b}$ & $1.74 \pm 0.04 b$ \\
\hline & 30 & $2.99 \pm 0.04 \mathrm{a}$ & $0.31 \pm 0.011 \mathrm{a}$ & $3.42 \pm 0.06 \mathrm{a}$ & $1.74 \pm 0.05 \mathrm{a}$ & $0.85 \pm 0.01 \mathrm{~d}$ & $4.02 \pm 0.08 \mathrm{a}$ & $2.05 \pm 0.05$ \\
\hline
\end{tabular}

Values are mean \pm SE $(n=10)$. The mean values in each column followed by different lowercase letters are significantly different by Fisher's least-significant difference test (LSD) at $P \leq 0.05$

common bean plants are presented in Table 4. Compared to the control treatment $(100 \%$ of the recommended dose of NPK), soil application with 10 ton OMF compost $\mathrm{h}^{-1}$, as an alternative to $50 \%$ of the recommended NPK dose, significantly decreased $(P \leq 0.05)$ the contents of $\mathrm{N}, \mathrm{P}$, $\mathrm{K}^{+}, \mathrm{Ca}^{2+}$, and $\mathrm{Na}^{+}$in bean leaves. However, the addition of either 20 or 30 ton OMF compost $\mathrm{h}^{-1}$ had no significant effects on the contents of $\mathrm{N}, \mathrm{P}, \mathrm{K}^{+}$, and $\mathrm{Ca}^{2+}$, while reduced significantly $(P \leq 0.05)$ the content of $\mathrm{Na}^{+}$. As for the ratios of $\mathrm{K}^{+}: \mathrm{Na}^{+}$and $\mathrm{Ca}^{2+}: \mathrm{Na}^{+}$, the highest significant values $(P \leq 0.05)$ were obtained with the application of 30 ton OMF compost $\mathrm{h}^{-1}$. This treatment significantly exceeded the treatment of 20 ton OMF compost $\mathrm{h}^{-1}$, which in turn surpassed significantly both the treatment of 10 ton OMF compost $\mathrm{h}^{-1}$ and the control. The same trend was noted in both the 2012 and 2013 seasons. These results showed more antagonistic effects of $\mathrm{K}^{+}$and $\mathrm{Ca}^{2+}$ ions to the harmful effects of $\mathrm{Na}^{+}$ions similar to that reported by Semida et al. (2014). However, application of OMF compost maintained no significant differences in the nutrient contents (i.e., N, P, K, and Ca) as in the control when NPK application was reduced to $50 \%$ of the recommended dose, in both 2012 and 2013 seasons. The OMF compost tested in the present study had a higher $\mathrm{N}$ content. It also 
represents a relatively abundant source of other minerals (Table 1). It may act as a reservoir for nutrients, ensuring their slow release into the soil or directly to plant roots. It has been shown that the OMF compost had beneficial effects on saline soil improvement. It improved the physical, chemical, and biological properties of saline soil and helped to overcome the loss of nutrients through leaching processes (Table 1).

\section{$\mathrm{NO}_{3}{ }^{-}$and $\mathrm{Cd}^{2+}$}

As an alternative to $50 \%$ of the recommended dose of NPK, the addition of OMF compost at a rate of 10,20, or 30 ton $\mathrm{ha}^{-1}$ showed significant decreases $(P \leq 0.05)$ in the concentrations of $\mathrm{NO}_{3}{ }^{-}$and $\mathrm{Cd}^{2+}$ of leaf, pod, and seed of common bean plants compared to the control treatment (100\% of the recommended dose of NPK; Table 5). There were no significant differences between the data obtained as a result of the application of OMF compost at rates of 20 and 30 ton $\mathrm{ha}^{-1}$, while both rates were more efficient in reducing the concentrations of $\mathrm{NO}_{3}{ }^{-}$and $\mathrm{Cd}^{2+}$ in leaf, pod, and seed of common bean plants than a rate of 10 ton $\mathrm{h}^{-1}$. The same trends were observed in both the 2012 and 2013 seasons. In this regard, Rady (2011a) concluded that soil application with a mixture of $\mathrm{KH}$ and FYM resulted in tomato leaves with lower $\mathrm{NO}_{3}{ }^{-}$content that was positively reflected in the $\mathrm{NO}_{3}{ }^{-}$content of the fruit for human nutrition and health. He also pointed out that increasing the available $\mathrm{N}$ in the soil by applying the recommended dose of mineral- $\mathrm{N}$ in the control fertilization regime led to a significant increase in the $\mathrm{NO}_{3}{ }^{-}$content of plant leaves that was also negatively reflected in the fruit. The accumulation of $\mathrm{NO}_{3}{ }^{-}$ions in edible plant parts poses a problem which can be attributed to the supply of readily available $\mathrm{NO}_{3}{ }^{-}$to the plants from mineral- $\mathrm{N}$ fertilizer. In contrast, the release of $\mathrm{NO}_{3}{ }^{-}$was comparatively slow in the organic fertilizertreated soil. In addition, an increase in the percentage of $\mathrm{OM}$ in the soil treated with organic fertilizers may control the release and transformation of $\mathrm{N}$ fertilizer to $\mathrm{NO}_{3}{ }^{-}$. Gairola et al. (2009) found that the addition of FYM to cultivated soil was effective in minimizing $\mathrm{NO}_{3}{ }^{-}$toxicity in beet leaves. They attributed this result to the incorporation of $\mathrm{OM}$, in the form of $\mathrm{FYM}$, which enhanced the organic carbon content of the soil and had direct and indirect effects on many soil properties and processes. The concentration of $\mathrm{NO}_{3}{ }^{-}$in NPK-fertilized plants was significantly higher than in organic crops. When organicbased fertilizer was used, the $\mathrm{NO}_{3}{ }^{-}$concentration was lower even at higher fertilizer levels. Benbrook et al. (2008) stated that fertilizers used in organic farms contain $\mathrm{N}$ bound to organic material from which it is slowly released. Readily soluble chemical fertilizers which are absorbed rapidly into the plant tend to lead to higher $\mathrm{NO}_{3}{ }^{-} /$ $\mathrm{NO}_{2}^{-}$levels and may result in the formation of nitrosamines which have been associated with chronic diseases such as leukemia and gastrointestinal cancers (Rembialkowska 2007). It would be best to use organic fertilizers for crop productions to minimize the harmful effects of $\mathrm{NO}_{3}{ }^{-}$to humans from the use of NPK.

Although $\mathrm{Cd}^{2+}$ is a non-essential element for crop plants, it is easily taken up by plants growing on $\mathrm{Cd}^{2+}$-supplemented or $\mathrm{Cd}^{2+}$-contaminated soils, entering food chain and causing damage to plant and human health (Kabata-Pendias and Pendias 2001). It has been reported that the mean concentration of $\mathrm{Cd}^{2+}$ ranges from 0.013 to $0.22 \mathrm{mg} \mathrm{kg}^{-1}$ for cereal grains and from 0.08 to $0.28 \mathrm{mg} \mathrm{kg}^{-1}$ for legumes (Kabata-Pendias and Pendias 2001). A number of approaches are being used to minimize the entry of $\mathrm{Cd}^{2+}$ into the

Table 5 Effect of OMF compost as a partial substitution of NPK on concentrations of $\mathrm{NO}_{3}{ }^{-}$and $\mathrm{Cd}^{2+}$ in Phaseolus vulgaris plants grown under soil salinity

\begin{tabular}{|c|c|c|c|c|c|c|c|}
\hline \multicolumn{2}{|l|}{ Treatments } & \multicolumn{6}{|l|}{ Parameters } \\
\hline $\begin{array}{l}\text { Recommended } \\
\text { NPK dose }\end{array}$ & $\begin{array}{l}\text { OMF compost } \\
\left(\text { ton } h^{-1} \text { ) }\right.\end{array}$ & $\begin{array}{l}\text { Leaf } \mathrm{NO}_{3}^{-}(\mathrm{mg} \\
\left.\mathrm{g}^{-1} \mathrm{DW}\right)\end{array}$ & $\begin{array}{l}\text { Leaf } \mathrm{Cd}^{2+}(\mathrm{mg} \\
\left.\mathrm{kg}^{-1} \mathrm{DW}\right)\end{array}$ & $\begin{array}{l}\mathrm{Pod} \mathrm{NO}_{3}^{-}(\mathrm{mg} \\
\left.\mathrm{g}^{-1} \mathrm{DW}\right)\end{array}$ & $\begin{array}{l}\text { Pod Cd }{ }^{2+}(\mathrm{mg} \\
\left.\mathrm{kg}^{-1} \mathrm{DW}\right)\end{array}$ & $\begin{array}{l}\text { Seed } \mathrm{NO}_{3}{ }^{-}(\mathrm{mg} \\
\left.\mathrm{g}^{-1} \mathrm{DW}\right)\end{array}$ & $\begin{array}{l}\text { Seed } \mathrm{Cd}^{2+}(\mathrm{mg} \\
\left.\mathrm{kg}^{-1} \mathrm{DW}\right)\end{array}$ \\
\hline \multicolumn{8}{|l|}{2012 season } \\
\hline \multicolumn{2}{|c|}{ Control (100\% NPK) } & $2.98 \pm 0.08 \mathrm{a}$ & $0.31 \pm 0.02 \mathrm{a}$ & $2.44 \pm 0.08 \mathrm{a}$ & $0.24 \pm 0.02 \mathrm{a}$ & $2.16 \pm 0.07 \mathrm{a}$ & $0.20 \pm 0.01 \mathrm{a}$ \\
\hline & 10 & $2.61 \pm 0.07 b$ & $0.18 \pm 0.01 b$ & $2.01 \pm 0.06 \mathrm{~b}$ & $0.12 \pm 0.01 b$ & $1.68 \pm 0.05 b$ & $0.10 \pm 0.01 b$ \\
\hline \multirow[t]{2}{*}{$50 \%$} & 20 & $2.39 \pm 0.06 \mathrm{c}$ & $0.15 \pm 0.01 \mathrm{c}$ & $1.86 \pm 0.05 \mathrm{c}$ & $0.09 \pm 0.01 \mathrm{c}$ & $1.40 \pm 0.04 \mathrm{c}$ & $0.07 \pm 0.01 \mathrm{c}$ \\
\hline & 30 & $2.36 \pm 0.06 \mathrm{c}$ & $0.15 \pm 0.01 \mathrm{c}$ & $1.83 \pm 0.05 \mathrm{c}$ & $0.09 \pm 0.01 \mathrm{c}$ & $1.38 \pm 0.04 \mathrm{c}$ & $0.07 \pm 0.01 \mathrm{c}$ \\
\hline \multicolumn{8}{|l|}{2013 season } \\
\hline \multicolumn{2}{|c|}{ Control (100\% NPK) } & $3.13 \pm 0.09 a$ & $0.33 \pm 0.02 \mathrm{a}$ & $2.51 \pm 0.07 \mathrm{a}$ & $0.27 \pm 0.02 \mathrm{a}$ & $2.22 \pm 0.06 \mathrm{a}$ & $0.19 \pm 0.01 \mathrm{a}$ \\
\hline & 10 & $2.60 \pm 0.07 b$ & $0.22 \pm 0.01 b$ & $1.96 \pm 0.05 b$ & $0.13 \pm 0.01 b$ & $1.56 \pm 0.05 b$ & $0.10 \pm 0.01 b$ \\
\hline \multirow[t]{2}{*}{$50 \%$} & 20 & $2.41 \pm 0.06 \mathrm{c}$ & $0.19 \pm 0.01 \mathrm{c}$ & $1.72 \pm 0.05 \mathrm{c}$ & $0.09 \pm 0.01 \mathrm{c}$ & $1.34 \pm 0.05 \mathrm{c}$ & $0.06 \pm 0.01 \mathrm{c}$ \\
\hline & 30 & $2.38 \pm 0.06 c$ & $0.17 \pm 0.01 \mathrm{c}$ & $1.68 \pm 0.04 \mathrm{c}$ & $0.08 \pm 0.01 \mathrm{c}$ & $1.31 \pm 0.04 \mathrm{c}$ & $0.06 \pm 0.01 \mathrm{c}$ \\
\hline
\end{tabular}

Values are mean \pm SE $(n=10)$. The mean values in each column followed by different lowercase letters are significantly different by Fisher's least-significant difference test (LSD) at $P \leq 0.05$ 
Table 6 Effect of OMF compost as a partial substitution of NPK on yields of Phaseolus vulgaris plants grown under soil salinity

\begin{tabular}{|c|c|c|c|c|c|}
\hline \multicolumn{2}{|l|}{ Treatments } & \multicolumn{4}{|l|}{ Parameters } \\
\hline $\begin{array}{l}\text { Recommended } \\
\text { NPK dose }\end{array}$ & $\begin{array}{l}\text { OMF compost } \\
\text { (ton } \mathrm{h}^{-1} \text { ) }\end{array}$ & $\begin{array}{l}\text { Pods weight } \\
\text { plant }^{-1}(\mathrm{~g})\end{array}$ & $\begin{array}{l}\text { Pods weight } \\
\text { (ton } \mathrm{ha}^{-1} \text { ) }\end{array}$ & $\begin{array}{l}\text { Seed weight } \\
\text { plant }^{-1}(\mathrm{~g})\end{array}$ & $\begin{array}{l}\text { Seed weight } \\
\text { (ton } \mathrm{ha}^{-1} \text { ) }\end{array}$ \\
\hline \multicolumn{6}{|l|}{2012 season } \\
\hline \multirow[t]{2}{*}{ Control (100\% NPK) } & & $60.7 \pm 3.4 \mathrm{a}$ & $8.97 \pm 0.5 \mathrm{a}$ & $12.7 \pm 0.8 \mathrm{a}$ & $1.82 \pm 0.12 \mathrm{a}$ \\
\hline & 10 & $50.0 \pm 2.7 b$ & $7.14 \pm 0.4 b$ & $10.5 \pm 0.6 b$ & $1.50 \pm 0.10 \mathrm{~b}$ \\
\hline \multirow[t]{2}{*}{$50 \%$} & 20 & $61.7 \pm 3.6 \mathrm{a}$ & $8.91 \pm 0.5 \mathrm{a}$ & $13.0 \pm 0.9 \mathrm{a}$ & $1.85 \pm 0.13 \mathrm{a}$ \\
\hline & 30 & $62.1 \pm 3.9 \mathrm{a}$ & $9.30 \pm 0.6 \mathrm{a}$ & $13.2 \pm 0.9 \mathrm{a}$ & $1.91 \pm 0.15 \mathrm{a}$ \\
\hline \multicolumn{6}{|l|}{2013 season } \\
\hline \multirow[t]{2}{*}{ Control (100\% NPK) } & & $63.2 \pm 4.1 \mathrm{a}$ & $9.02 \pm 0.6 \mathrm{a}$ & $13.3 \pm 1.1 \mathrm{a}$ & $1.90 \pm 0.14 \mathrm{a}$ \\
\hline & 10 & $48.9 \pm 2.9 b$ & $6.98 \pm 0.4 b$ & $10.3 \pm 0.7 b$ & $1.46 \pm 0.10 \mathrm{~b}$ \\
\hline \multirow[t]{2}{*}{$50 \%$} & 20 & $63.7 \pm 4.4 \mathrm{a}$ & $9.10 \pm 0.6 \mathrm{a}$ & $13.4 \pm 1.2 \mathrm{a}$ & $1.91 \pm 0.13 \mathrm{a}$ \\
\hline & 30 & $65.8 \pm 4.7 \mathrm{a}$ & $9.42 \pm 0.7 \mathrm{a}$ & $13.8 \pm 1.4 \mathrm{a}$ & $1.98 \pm 0.14 \mathrm{a}$ \\
\hline
\end{tabular}

Values are mean $\pm \mathrm{SE}(n=10)$. Mean values in each column followed by different lowercase letters are significantly different by Fisher's leastsignificant difference test (LSD) at $P \leq 0.05$

plants. Soil application of organic fertilizers is one of the good strategies to alleviate the damaging effects of $\mathrm{Cd}^{2+}$ on plants and to avoid its entry into plants (Table 1) and subsequently the food chain as shown in the present study. $\mathrm{Cd}^{2+}$ was found to bind to the organic matter existing in soil, and to rule out away from the plant roots (Baranski et al. 2014). The results of hundreds of works indicated that organic crops have a higher antioxidant activity and a lower concentration of $\mathrm{Cd}^{2+}$ compared to inorganic crops (Baranski et al. 2014). This is in accordance with our results (Table 5), which showed that plants that received the full recommended NPK fertilizer dose had $\mathrm{Cd}^{2+}$ concentrations above the limits determined in legumes, while those that received OMF compost as an alternative to $50 \%$ of the recommended NPK fertilizer dose had $\mathrm{Cd}^{2+}$ concentrations below the limits (0.28 $\mathrm{mg} \mathrm{kg}^{-1}$; Kabata-Pendias and Pendias 2001).

\section{Common bean yields}

As an alternative to $50 \%$ of the recommended dose of NPK, addition of OMF compost at a rate of 10 ton ha ${ }^{-1}$ showed significant reductions $(P \leq 0.05)$, while application of a rate of 20 or 30 ton $\mathrm{h}^{-1}$ revealed no significant differences $(P \leq 0.05)$ in common bean yield characteristics (in terms of pod weight per plant and per hectare, and seed weight per plant and per hectare) when compared with the control treatment $(100 \%$ of the recommended dose of NPK; Table 6). The same trends were observed over both growing seasons. The favorable yields obtained with OMF compost used in the current study were at a rate of 20 or 30 ton $\mathrm{h}^{-1}$ combined with $50 \%$ of the recommended dose of the NPK fertilizers. This could be attributed to the positive combined effects of the OMF compost and NPK fertilizers, which show the fast release of nutrients from the
NPK fertilizers for seedlings at the early stage of growth and slow release of these nutrients from the OMF compost for plants at the late stages of growth. This reflects an increase in the pod and seed yields, or an equivalent yield to the control using OMF compost as a soil conditioner with the reduction of NPK to $50 \%$ of the recommended dose. However, 20 ton OMF compost ha ${ }^{-1}$ is preferable for achieving the greatest yields and highest soil fertility in the long run. It seems likely that mineral elements released from the decayed compost (more nutrient availability, Table 1) would be closely related to the improved leaf photosynthetic pigments (Table 3) and plant nutritional status (Table 4), reflecting in the plant growth rate. This improved plant growth rate reflected, in turn, in enhanced green and dry yields. Taken together, the combined treatment of 20 ton OMF compost ha ${ }^{-1}$ and 50\% NPK enabled plants to overcome many of the adverse effects of soil salinity. $\mathrm{KH}$ and $\mathrm{S}$, as components of the OMF compost, have often been proposed as additives for saline soils to improve crop production. They have also been suggested as soil amendments to protect plants against various abiotic stresses (Adani et al. 1998). In addition, FYM as one of the OMF compost components has the benefit to improve crop production similar to the results obtained by Singh et al. (2015) on the cotton and peanut intercropping system. Similar results were obtained by Kumar et al. (2014) and Suja and Sreekumar (2014).

\section{Conclusions}

The OMF compost at a rate of 20 ton $\mathrm{h}^{-1}$ showed promise, as an alternative to $50 \%$ of the recommended dose of NPK fertilizers, for common bean production with low 
pollutants for human nutrition and health. This treatment showed lower concentrations of $\mathrm{Cd}^{2+}$ and $\mathrm{NO}_{3}{ }^{-}$than the control, increasing yield quality and maintaining the same yield quantity. It is therefore reasonable to recommend the use of OMF compost as an alternative to $50 \%$ of the recommended NPK dose. Further studies are needed to focus on the bio-availability of the degraded fractions of the OMF compost in the soil solution, rhizosphere, and the relationships between the activities of these fractions and the metabolism of soil micro-organisms and their effects on plant metabolism.

Open Access This article is distributed under the terms of the Creative Commons Attribution 4.0 International License (http://crea tivecommons.org/licenses/by/4.0/), which permits unrestricted use, distribution, and reproduction in any medium, provided you give appropriate credit to the original author(s) and the source, provide a link to the Creative Commons license, and indicate if changes were made.

\section{References}

Abdelhamid MT, Horiuchi T, Oba S (2004) Composting of rice straw with oilseed rape cake and poultry manure and its effects on faba bean (Vicia faba L.) growth and soil properties. Bioresour Technol 93:183-189

Adani F, Genevini P, Zaccheo P, Zocchi G (1998) The effect of commercial humic acid on tomato plant growth and mineral nutrition. J Plant Nutr 21:561-575

AOAC (1995) Official methods of analysis of the association of official agricultural chemists, 16th edn. Washington, DC, USA

Arnon DI (1949) Copper enzymes in isolated chloroplast, polyphenoloxidase in Beta vulgaris L. Plant Physiol 24:1-5

Baranski M, Srednicka-Tober D, Volakakis N, Seal C, Sanderson R, Stewart GB, Benbrook C, Biavati B, Markellou E, Giotis C, Gromadzka-Ostrowska J, Rembiałkowska E, Skwarło-Sonta K, Tahvonen R, Janovská D, Niggli U, Nicot P, Leifert C (2014) Higher antioxidant and lower cadmium concentrations and lower incidence of pesticide residues in organically grown crops: a systematic literature review and meta-analyses. $\mathrm{Br} \mathrm{J}$ Nutr 112:794-811

Bates LS, Waldeen RP, Teare ID (1973) Rapid determination of free proline for water stress studies. Plant Soil 39:205-207

Benbrook C, Zhao X, Yáñez J, Davies N, Andrews P (2008) New evidence confirms the nutritional superiority of plant-based organic foods. State of science review. The Organic Center: Boulder

Chapman HD, Pratt PF (1961) Methods of analysis for soil, plants and water. University of California, Division of Agricultural Science, Berkeley, CA, USA, pp 56-63

Dotaniya ML, Datta SC, Biswas DR, Dotaniya CK, Meena BL, Rajendiran S, Regar KL, Lata M (2016) Use of sugarcane industrial by-products for improving sugarcane productivity and soil health. Int J Recycl Org Waste Agric 5:185-194

Egyptian Ministry of Agriculture (2011) Agricultural Production in Egypt. http://www.agregypt.gov.eg/5-

Erdal Ý, Bozkurt MA, Çimrin KM, Karaca S, Saðlam M (2000) Effects of humic acid and phosphorus applications on growth and phosphorus uptake of corn plant (Zea mays L.) grown in a calcareous soil. Turk J Agric For 24:663-668
Gairola S, Umar S, Suryapani S (2009) Nitrate accumulation, growth and leaf quality of spinach beet (Beta vulgaris Linn.) as affected by NPK fertilization with special reference to potassium. Ind J Sci Technol 2:35-40

Golueke CG (1972) In: Emmaus (ed) Composting: a study of the process and its principles. Rodale Press, p 110

Habashy N, Ewees MSA (2011) Improving productivity of zucchini squash grown under moderately saline soil using gypsum, organo-stimulants and AM-fungi. J Appl Sci Res 7(12):2112-2126

Hayat S, Ali B, Hasan SA, Ahmad A (2007) Brassinosteroid enhanced the level of antioxidants under cadmium stress in Brassica juncea. Environ Exp Bot 60:33-41

Irigoyen JJ, Emerich DW, Sanchez-Diaz M (1992) Water stress induced changes in the concentrations of proline and total soluble sugars in nodulated alfalfa (Medicago sativa) plants. Physiol Plant 8:455-460

Isopp H, Frehner M, Almeida J, Blum H, Daepp M, Hartwig U, Lüscher A, Suter D, Nösberger J (2000) Nitrogen plays a major role in leaves when source-sink relations change: $\mathrm{C}$ and $\mathrm{N}$ metabolism in Lolium perenne growing under free air $\mathrm{CO}_{2}$ enrichment. Aust J Plant Physiol 27:851-858

Jackson ML (1967) Soil chemical analysis. Prentice Hall of India Pvt. Ltd, New Delhi, pp 144-197, 326-338

Kabata-Pendias A, Pendias H (2001) Trace elements in soils and plants, 3rd edn. CRC Press, Boca Raton

Kalaivanan D, Hattab KO (2016) Recycling of sugarcane industries byproducts for preparation of enriched pressmud compost and its influence on growth and yield of rice (Oryza sativa L.). Int $\mathrm{J}$ Recycl Org Waste Agric 5:263-272

Kulikova NA, Stepanova EV, Koroleva OV (2005) Mitigating activity of humic substances: direct influence on biota. In: Perminova IV, Hatfield K, Hertkorn N (eds) Use of humic substances to remediate polluted environments: from theory to practice. NATO Science Series. IV: Earth and Environmental Sciences, vol 52. Springer, Dordrecht, pp 285-310

Kumar V, Chopra AK (2016) Effects of sugarcane pressmud on agronomical characteristics of hybrid cultivar of eggplant (Solanum melongena L.) under field conditions. Int J Recycl Org Waste Agric 5:149-162

Kumar R, Sood S, Sharma S, Kasana RC, Pathania VL, Singh B, Singh RD (2014) Effect of plant spacing and organic mulch on growth, yield and quality of natural sweetener plant Stevia and soil fertility in western Himalayas. Int J Plant Prod 8(3):311-334

Lachica M, Aguilar A, Yanez J (1973) Analisis foliar. Métodos utilizados enla EstaciLn Experimental del Zaidin. Anales de Edafologia y Agrobiologia 32:1033-1047

Marschner H (1995) Mineral nutrition of higher plants, 2nd edn. Academic Press Publication, New York, pp 559-579

McLaughlin MJ, Bell MJ, Wright GC, Cozens GD (2000) Uptake and partitioning of cadmium by cultivars of peanut (Arachis hypogea L.). Plant Soil 222:51-58

Moyin-Jesu EI (2015) Use of different organic fertilizers on soil fertility improvement, growth and head yield parameters of cabbage (Brassica oleraceae L). Int J Recycl Org Waste Agric 4:291-298

Ojo JA, Olowoake AA, Obembe A (2014) Efficacy of organomineral fertilizer and un-amended compost on the growth and yield of watermelon (Citrullus lanatus Thumb) in Ilorin Southern Guinea Savanna zone of Nigeria. Int J Recycl Org Waste Agric 3:121-125

Okusami RA, Rust RH, Alao AO (1997) Red soils of different origins from southwest Nigeria: characteristics, classification and management considerations. Can J Soil Sci 77:295-307

Osman ASh, Rady MM (2012) Ameliorative effects of sulphur and humic acid on the growth, antioxidant levels, and yields of pea 
(Pisum sativum L.) plants grown in reclaimed saline soil. J Hortic Sci Biotechnol 87(6):626-632

Ouni Y, Ghnaya T, Montemurro F, Abdelly Ch, Lakhdar A (2014) The role of humic substances in mitigating the harmful effects of soil salinity and improve plant productivity. Int J Plant Prod 8(3):353-374

Premchandra GS, Saneoka H, Ogata S (1990) Cell membrane stability, an indicator of drought tolerance as affected by applied nitrogen in soybean. J Agric Sci Camb 115:63-66

Rady MM (2011a) Effects on growth, yield, and fruit quality in tomato (Lycopersicon esculentum Mill.) using a mixture of potassium humate and farmyard manure as an alternative to mineral-N fertiliser. J Hortic Sci Biotechnol 86(3):249-254

Rady MM (2011b) Effect of 24-epibrassinolide on growth, yield, antioxidant system and cadmium content of bean (Phaseolus vulgaris L.) plants under salinity and cadmium stress. Sci Hortic 129(2):232-237

Rady MM, Bhavya Varma C, Howladar SM (2013) Common bean (Phaseolus vulgaris L.) seedlings overcome $\mathrm{NaCl}$ stress as a result of presoaking in Moringa oleifera leaf extract. Sci Hortic 162:63-70

Rembialkowska E (2007) Quality of plant products from organic agriculture. J Sci Food Agric 87:2757-2762

Riaz A, Younis A, Ghani I, Tariq U, Ahsan M (2015) Agricultural waste as growing media component for the growth and flowering of Gerbera jamesonii cv. hybrid mix. Int J Recycl Org Waste Agric 4:197-204

Semida WM, Abd El-Mageed TA, Howladar SM (2014) A novel organo-mineral fertilizer can alleviate negative effects of salinity stress for eggplant production on reclaimed saline calcareous soil. Acta Hortic 1034:493-499

Semida WM, Rady MM, Abd El-Mageed TA, Howladar SM, Abdelhamid MT (2015) Alleviation of cadmium toxicity in common bean (Phaseolus vulgaris L.) plants by the exogenous application of salicylic acid. J Hortic Sci Biotechnol 90(1):83-91

Sinclair TR, Ludlow MM (1986) Influence of soil water supply on the plant water balance of four tropical grain legumes. Aust J Plant Physiol 13:329-341

Singh RJ, Ahlawat IPS, Sharma NK (2015) Resource use efficiency of transgenic cotton and peanut intercropping system using modified fertilization technique. Int J Plant Prod 9(4):523-540

Smith GH, Chaney K, Murray C, Le MS (2015) The effect of organomineral fertilizer applications on the yield of winter wheat, spring barley, forage maize and grass cut for silage. J Environ Protect 6:103-109

Suja G, Sreekumar J (2014) Implications of organic management on yield, tuber quality and soil health in yams in the humid tropics. Int J Plant Prod 8(3):291-310

Sullivan CY, Ross WM (1979) Selecting the drought and heat resistance in grain sorghum. In: Mussel H, Staples RC (eds) Stress physiology in crop plants. Wiley, New York, pp 263-281

Wolf B (1982) A comprehensive system of leaf analysis and its use for diagnosing crop nutrients status. Commun Soil Sci Plant Anal 13:1035-1059

Zhang T (1998) Quick nitrate test for hybrid sudangrass and pearl millet hays, vol 31. Forage Management College: Stillwater, OK, USA, pp 2127-2132 